\title{
FORMS OF EMPLOYEE TRAININGS CONCERNING ASPECTS OF COLD KNOWLEDGE
}

\author{
Marcin Komańda
}

University of Economics in Katowice, Poland, marcin.komanda@ue.katowice.pl

\begin{abstract}
Research relevance: Cold knowledge is perceived as a key issue in terms of the composition of the company and the sense of the procedures being implemented. Thus, organisation of appropriate forms of employee trainings in this regard becomes essential. Aim of the paper: Distinguishing the existence of schemes of applied forms of employee trainings in the contexts of relation between two aspects of cold knowledge (internal documentation and data bases) and the types of enterprises (their formal independence). Research methods applied: A survey based on the purposive sampling of respondents was conducted. A two-tiered clustering analysis and an analysis of correspondence were applied. Main findings: It was possible to distinguish four groups of particular forms of trainings. Three groups are represented by the same main forms of trainings in both cases (documentation/databases). The analysis of correspondence established that respondents from branches as well as head offices of multi-branch enterprises were, in case of trainings concerning internal documentation, more prone to point at two forms of trainings: blended and special, whereas, in case of training within the scope of databases, they were more willing to point at a special form of trainings. Theoretical and/or practical value of the study: Results allow to associate the forms of employee trainings in the chosen aspects of cold knowledge and show the differentiation of their use depending on the type of enterprise. These facts open up a new theoretical perspective for the description of organisation of employee trainings based on formal relations.
\end{abstract}

Keywords: training; knowledge, employee; organisation.

JEL Classification: M12, M19

\section{Introduction}

The problem of learning within an enterprise is a comprehensive issue. It requires making references to multiple issues related, amongst other things, to the level of learning within an organisational hierarchy, the nature of this process (adaptability to changes, anticipation of reality, review of the learning process itself) and, finally, conditionings of its course (Senge 1997). Today, dynamic capabilities are identified as the main perspective of the organisational learning description. The most important is the absorptive capacity, which is related to the organisational learning in the context of new external knowledge (Sun, Anderson 2010). All of these issues together in the management sciences are referred to as a learning organisation, and they are related to the issues of knowledge management within an enterprise; however, the relationships between these two concepts tend to cause a lot of difficulty in their unambiguous comparison.

Learning of an organisation, including its members, is related to gaining knowledge, understanding it as well as understanding of the learning process itself and improving the effects of the conducted activity (Garvin 2003). It may be connected with entrepreneurial orientation (Real et al. 2014). These challenges are, in turn, connected with the necessity to obtain knowledge from any available source and to apply it in practice, which leads to initiation and undertaking of changes (Senge et al. 1999). From this perspective, not only do these changes become a natural aspect of conducting business activity, but from the perspective of the competitive battle being waged, they also require an enterprise to devise suitable competences, which are connected with gaining and using knowledge and which have been shaped in the situational context of the organisation itself (Dziubińska 2009).

Nowadays, the sources of competitive advantage are to be looked for within implemented innovations. 
Therefore, ensuring, above all, appropriate organisational culture that supports the process of devising and introducing changes constitutes a significant issue of a learning organisation. In the light of the conducted studies, the size of an enterprise itself seems to be insignificant in this case (Ismail 2005). For organisational learning to be able to bring desirable results, it is postulated that it should also be based on (by means of organisational culture, amongst other things), above all, understanding of the dynamics and complexity of the circumstances of conducting a business activity, as well as development of skills of particular individuals connected with comprehension and assessment of a real situation, within an organisation itself, and development of these skills on a group level. These issues are related to the use of knowledge to improve the results of the performance (Jaafar et al. 2014). It is also postulated that the aspects of the assumed ethical model in enterprise management should be taken into consideration and applied or that the common vision in an organisation of what is being done should be revived (Rowley, Gibbs 2008).

The related issue of knowledge management seems to be very interesting in this context. It may be presented in three main perspectives. First, as an aspect of a conducted business activity concentrated on the processes of gaining knowledge, its assessment, processing and use. The second perspective concerns the form of knowledge assets gained by an enterprise as well as those that an enterprise already possesses. The third perspective (cognitivist) concerns the insight into the essence of knowledge itself and ways of its transformation into various manifestations (Dalkir, Liebowitz 2011). Knowledge management in an enterprise is, therefore, focused on, above all, knowledge resources themselves (Geisler, Wickramasinghe 2015) and procedures of their dissemination and application (Aggestam 2015). The efficiency of these actions depends, in turn, on the adjustment of knowledge to the existing need. Therefore, both codification of knowledge into desirable forms as well as its transfer with the use of appropriate tools take place (Ruggles 2009). Nowadays, these tools are related to, above all, information infrastructure and software (including database structures, data processing and visualisation), and they are involved in the use of available functional options not only of members of an enterprise but often also of its contractors or clients (Sztangret, Bilińska-Reformat 2014), dependent companies and enterprise representatives in various geographical locations (Jędralska et al. 2013). At the same time, the results of research works indicate that ICT practices contribute to financial performance only when they are linked to human resource management (HRM) practices (Andreeva, Kianto 2012).

Therefore, mentioning of the concept of knowledge management makes it possible to establish the complexity of organisational learning that must be characterised by not only the understanding of learning itself and the necessity to translate gained knowledge into a practical dimension but also the awareness of possibilities and limitations of tools being used for this purpose and knowledge-oriented leadership (Donate, de Pablo 2015). The enterprise, as Kim states, learns regardless of its individual members but not regardless of all of them. The key aspects of relationships between individual and organisational learning are the aspects related to the understanding of this process (mostly in the following dimensions: 'what for' and 'how') as well as their confrontation with organisational routines and visions shared within an enterprise (Kim 1998). Individual mistakes should be allowed and individual contribution evaluation should be implemented (Driscoll 2014). Organisation of employee's trainings becomes an aspect that requires special attention in the light of the concept of learning organisation and knowledge management.

The rules concerning creating, circulation as well as use of information resources connected with internal documentation and databases within an enterprise are regarded as a significant element of cold knowledge in the knowledge system of the enterprise. Cold knowledge offers the understanding of organisational routines, sense and rules of employee performance. Thus, organisation of appropriate forms of employee trainings in this regard becomes essential. Therefore, the specific objectives of this paper are to distinguish the schemes of applied forms of organisation of employee trainings within business entities represented by the surveyed respondents and to determine whether there is a relationship between them and the type of an enterprise itself (in prospect of its formal independence). A survey based on the purposive sampling of respondents was conducted for the purposes of the paper (in the number of 215). In order to achieve objectives, a two-tiered clustering analysis and an analysis of correspondence were applied. Non-probabilistic sampling of respondents makes the results of the 
conducted analysis impossible to be referred to the entire population.

\section{Literature Review}

The scope of training programmes offered to employees of enterprises should be considered in the wider perspective. It consists of the needs of an individual member of an organisation resulting from their skills, competences and situational context of their professional responsibilities in the system of the enterprise (Sergeev, Babkin 2015). The context of professional responsibilities from the perspective of planning and organisation of trainings, in turn, consists of the foregoing experiences of an organisation related to who should be trained and what problems an employee who was given the responsibilities will potentially have to face (Mathieu, Martineau1997).

It is assumed that an organisation and conducting of employee trainings are supposed to promote an increase in productivity within an enterprise. It needs to meet the goals of enterprise and employees (Ocieczek et al. 2016). Development of employee skills as a desirable effect of such training justifies this expectation. However, the condition for such mechanism to exist is not only a properly selected training but also engagement of employees themselves. What seems to be of key significance in this perspective is noticing that trainings may concern particular aspects of the job done or they may be of general nature. Employee's engagement and, as a consequence, an increase in their productivity seem to occur, above all, in case of general trainings. There are two possible explanations for this fact. First, such trainings may be regarded by an employee as a professional bonus that favours psychological effect of employee's attachment to an enterprise. Second, general trainings may be considered by employees to be an opportunity to develop additional skills, which may turn out to be useful in a different workplace (Barrett, O'Connell 2001). The conducted studies also pointed out that trainings are organised mostly for technical employees and specialists (Osterman 1995). Contemporary research papers also touch on the problem of the emotional state of employees and its impact on job satisfaction (Vatansever, Karamaraş 2017).

Apart from specially organised trainings for employees, there is also a form of practical knowledge acquisition within an enterprise. This practical learning by means of performing professional duties is even regarded as the main form of knowledge acquisition within an organisation. However, this form is very often used by managers as an unstructured and cost-efficient (or even cost-free) one. It means that conducting trainings sometimes becomes the responsibility of other employees who may be professionally experienced but do not necessarily possess high training qualifications within the scope of practical teaching and conducting trainings. This kind of freedom in organisation and implementation of this type of trainings within organisations is often criticised (Jacobs 2003).

From the theoretical perspective, however, learning by means of practical implementation of professional duties, however, should meet a number of requirements. There should be a person appointed to supervise and monitor the learning process itself, offer essential assistance and advise to a person being trained or to prepare prospective training materials that would support completion of tasks. It is also significant, from the perspective of prospective effects of such trainings, to encourage an employee to engage in the implemented training (Billett 2001). Stimulation of professional development and simultaneous motivation of employees are still outstanding challenges of human resources management (Livitchi et al. 2015).

Nowadays, for the purposes of each form of training and subject information technology, tools might be applied. The information system of an enterprise may serve as an environment where employee trainings may be organised and monitored. In the case of using the information technology, the training of employees indicates positive results: reduction of the costs, saving time and improvement of learning (Rezaei et al. 2014). Apart from the access to standard documentation of an enterprise, databases and prepared materials, the system may also offer the possibility to contact experts and review specialist reports (Rosenberg 2001), which causes a fully implemented training of this kind to have a more organised form as it assumes a mixed form between an implemented, and very often costefficient, form of learning by acting and a specially organised training. It is postulated that in a contemporary enterprise with fully developed human resources management, employee trainings of varied forms should take place everywhere and any time (Lendzion 2015). 
Taking this fact into consideration, it should be made clear that implemented practices within the scope of employee trainings may also involve issues related to learning and transfer of knowledge between the units of an enterprise, including its various geographical locations (Minbaeva et al. 2003). From this perspective, employee trainings are implemented by taking into account formal relationships between units of an enterprise that create the context of tasks of a unit as well as responsibilities of its employees, and they are implemented together with other activities concerning human resources management (Minbaeva 2005). The problem of formal and legal association of enterprises also remains in the interest of researchers in the perspective of work organisation between partners (above all in the context of strategic alliances) (Albers et al. 2016).

Therefore, it becomes necessary to properly solve the issue of employee learning whilst placing the potential solution between the dimensions of their personal motivation and experience (hot knowledge within an organisation) and formal rules and regulations of work, including organisational routines (Komańda 2016). These aspects become especially significant in the context of procedures of creating and using specific resources of knowledge of an enterprise, such as internal documentation of an enterprise as well as organisational databases. Together with formal rules, they constitute the so-called resources of cold knowledge within an organisation (Komańda 2017). Such direction of research seems to be justified by the current research results, which suggest that in case of companies operating in the so-called less knowledge-intensive conditions, the key aspects of the creation of new knowledge resources are organisational documentation and knowledge sharing (Andreeva, Kianto 2011).

\section{Methodology}

A survey based on the purposive sampling of respondents was conducted for the purposes of the work. The selection of respondents was not probabilistic, and it assumed the form of convenience sampling (Martens 2014). The availability of respondents became the discretion criterion for their selection for the researcher (Rószkiewicz et al. 2013). This enabled the researcher to obtain a broad group of respondents who were requested to fill in the survey in the paper form (PSAQ - Paper SelfAdministered Questionnaires). The number of respondents whose questionnaires were qualified for the research amounted to 215. Each of the respondents represented a different enterprise. They were also people holding various positions in an organisation. The majority of respondents $(184 ; 85.6 \%)$ represented enterprises located on the territory of the Silesian Voivodeship. This may be regarded as a result of the applied method for the selection of respondents.

Two research questions were formulated in relation to the issues concerning organisation of trainings in the context of cold knowledge resources within an enterprise outlined in the theoretical perspective. The first one is related to whether it is possible to group the surveyed entities according to schemes of applied organisational forms of professional trainings within the scope of popularisation and consolidation of formal rules of creating and using internal documentation and databases. The following answer variants corresponding to the levels of formal training organisation were assumed: special training, training by performing responsibilities, a mixed form of the first two trainings and lack of trainings. The other question is about establishing the structure of relationships between respondents' indications concerning the type of trainings conducted within an enterprise in the abovementioned areas and the type of an enterprise itself. Whilst speaking about the type of an enterprise, one might take into consideration whether it is a single-branch enterprise, a unit of a multi-branch enterprise or a seat of a multi-branch enterprise. Single-branch enterprises were represented in the study by 99 people $(46.05 \%)$; next there were respondents who represented the companies that were the units of multi-branch enterprises $(91 ; 42.32 \%)$ and those that were the seats of multi-branch enterprises $(25 ; 11.63 \%)$. The issue of potential formal independence of an entity or its subordination/precedence in relation to another entity has an impact on internal formal regulations. Therefore, it also seems to translate into the issue concerning organisation of employee trainings within an enterprise. Respondents were allowed to indicate one version of the answer to each question.

The collected data of nominal nature determined the choice of statistical analysis methods. The twolevel clustering analysis was applied for data processing in case of the first question, whereas in case 
of the second one, the correspondence analysis was used (symmetric normalisation method). The gathered data was analysed with the use of the programme for statistical computing PS Imago (SPSS 23).

\section{Results}

The conducted two-level cluster analysis made it possible to group the respondents' opinions about applied forms of trainings in their enterprises within the scope of popularisation and consolidation of formal rules of creation and use of internal documentation of databases (regarded in this case as predictors) into two clusters. This grouping obtained a satisfactory cohesion and separation measure (the so-called Silhouette coefficient). The value of this coefficient amounted to 0.6, and it signifies the so-called serious class structure (Kisielińska 2009).

The 'form of training within databases' variable turned out to be the most significant predictor (the value of 1.00). The value of the 'form of training within internal documentation' as a predictor of grouping amounted to 0.49 . The count of particular groups is presented in Table 1 . The ratio of the size of the largest group to the smallest one amounted to 1.73 .

Table 1. The results of grouping of entities according to the form of trainings within the scope of popularisation and consolidation of formal rules of creating and applying internal documentation and databases (Source: author's compilation)

\begin{tabular}{|l|l|l|l|l|}
\hline Group & $\mathbf{1}$ & $\mathbf{2}$ & $\mathbf{3}$ & $\mathbf{4}$ \\
\hline $\begin{array}{l}\text { Size (number of assigned } \\
\text { entities) }\end{array}$ & $60(27.9 \%)$ & $40(18.6 \%)$ & $46(21.4 \%)$ & $69(32.1 \%)$ \\
\hline $\begin{array}{l}\text { Forms of trainings within the } \\
\text { scope of formal rules of creating } \\
\text { and applying databases (the } \\
\text { most frequent attributes } \\
\text { amongst indications of the } \\
\text { group) form }\end{array}$ & $\begin{array}{l}\text { Mixed Special trainings } \\
(100 \%)\end{array}$ & $\begin{array}{l}\text { Lack of trainings } \\
(100 \%)\end{array}$ & $\begin{array}{l}\text { Through } \\
\text { performance of } \\
\text { responsibilities } \\
(100 \%)\end{array}$ \\
\hline $\begin{array}{l}\text { Forms of trainings within the } \\
\text { scope of formal rules of creating } \\
\text { and applying internal } \\
\text { documentation (the most } \\
\text { frequent attributes amongst } \\
\text { indications of the group) }\end{array}$ & $\begin{array}{l}\text { Mixed form } \\
(43.3 \%)\end{array}$ & $\begin{array}{l}\text { Special trainings } \\
(60 \%)\end{array}$ & $\begin{array}{l}\text { Through } \\
\text { performance of } \\
\text { responsibilities } \\
(56.5 \%)\end{array}$ & $\begin{array}{l}\text { Through } \\
\text { performance of } \\
\text { responsibilities } \\
(100 \%)\end{array}$ \\
\hline
\end{tabular}

Forms of trainings such as 'mixed form' and 'through performance of responsibilities' may be distinguished in group 2 in case of forms of trainings within the scope of internal documentation. In group 3, in case of trainings concerning internal documentation, 'lack of trainings' may be distinguished as well, whereas the case of group 1 seems to be the most diversified. In case of trainings regarding databases, 'lack of trainings' and 'through performance of responsibilities' may be distinguished apart from the dominant indication, whereas in case of trainings within the scope of documentation for this group, another three forms of trainings occur apart from the main indication.

The correspondence table (Table 2) reveals the structure of respondents' responses to questions about the type of an enterprise and the form of trainings in the scope of internal documentation. Figure 1 shows the results of the correspondence analysis conducted for the purposes of answering the question concerning the structure of relationships between the type of enterprises and applied forms of trainings within the scope of popularisation and consolidation of formal rules of creating and applying internal documentation. 
Table 2. Correspondence table for trainings within the scope of internal documentation and the type of an enterprise (Source: author's compilation)

\begin{tabular}{|c|c|c|c|c|}
\hline \multirow[b]{2}{*}{$\begin{array}{l}\text { Trainings within the scope o } \\
\text { internal documentation }\end{array}$} & \multicolumn{4}{|c|}{ Type of an enterprise } \\
\hline & $\begin{array}{l}\text { Single-branch } \\
\text { enterprise }\end{array}$ & $\begin{array}{l}\text { Seat of the multi- } \\
\text { branch enterprise }\end{array}$ & $\begin{array}{l}\text { Unit of the multi- } \\
\text { branch enterprise }\end{array}$ & Active margin \\
\hline Lack of trainings & 14 & 0 & 11 & 25 \\
\hline Through performance & 60 & 8 & 37 & 105 \\
\hline Special trainings & 13 & 8 & 29 & 50 \\
\hline Mixed form of trainings & 12 & 9 & 14 & 35 \\
\hline Active margin & 99 & 25 & 91 & 215 \\
\hline
\end{tabular}

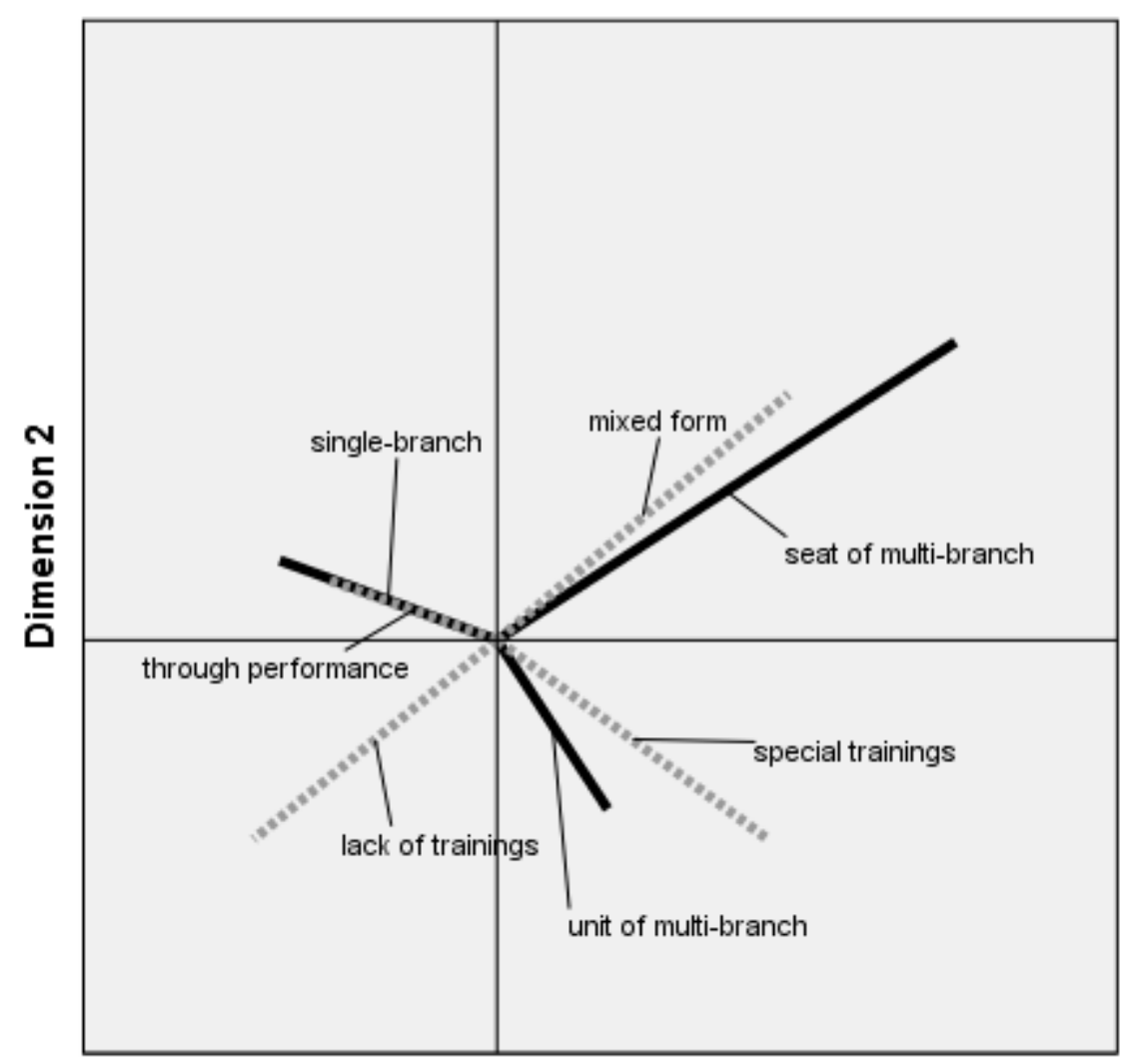

Dimension 1

Fig. 1. The results of the correspondence analysis for variables related to trainings within the scope of internal documentation and type of an enterprise (Source: author's compilation)

It should be emphasised that two dimensions served as an explanation of the whole inertia of the table. Dimension 1 explained $80.3 \%$ of inertia. The value of the chi-square test amounted to 24.123 , whereas the level of significance was $p=0.000$. All categories were characterised by mass values above 0.05 ; therefore, it was not necessary to mark any of them as passive. Dimension 1 distinguishes a singlebranch enterprise from a unit of a multi-branch enterprise as well as from a seat of a multi-branch enterprise. Respondents representing single-branch enterprises in the structure of answers were more likely to point at 'lack of trainings' or organisation of trainings 'through performance of professional responsibilities'. 'Lack of trainings' and 'special trainings' accounted for a relatively large share in the structure of indications for units of multi-branch enterprises (dimension 2). The indication 'through performance of responsibilities' has the largest share in the structure of indications for a single-branch 
enterprise, whereas in case of a headquarters of a multi-subsidiary enterprise, it was 'mixed form of trainings' (approach of points). Variability of distribution was mostly influenced by 'mixed form of training' and 'seat of a multi-branch enterprise' (the longest vectors in particular groups of the category).

The correspondence analysis was conducted again; however, this time it is for the variable form of trainings within the scope of popularisation and consolidation of formal rules of creating and applying resources of databases. Table 3 reveals the structure of respondents' responses to questions about the type of an enterprise and the form of trainings in the scope of databases.

Table 3. Correspondence table for trainings within the scope of databases and the type of an enterprise (Source: author's compilation)

\begin{tabular}{|l|c|c|c|c|}
\hline \multirow{2}{*}{$\begin{array}{l}\text { Trainings within the scope of } \\
\text { databases }\end{array}$} & $\begin{array}{l}\text { Type of an enterprise } \\
\text { Single-branch } \\
\text { enterprise }\end{array}$ & $\begin{array}{l}\text { Seat of the multi- } \\
\text { branch enterprise }\end{array}$ & $\begin{array}{l}\text { Unit of the multi- } \\
\text { branch enterprise }\end{array}$ & Active margin \\
\hline Lack of trainings & 30 & 4 & 27 & 61 \\
\hline Through performance & 46 & 9 & 34 & 89 \\
\hline Special trainings & 10 & 7 & 23 & 40 \\
\hline Mixed form of trainings & 13 & 5 & 7 & 25 \\
\hline Active margin & 99 & 25 & 91 & 215 \\
\hline
\end{tabular}

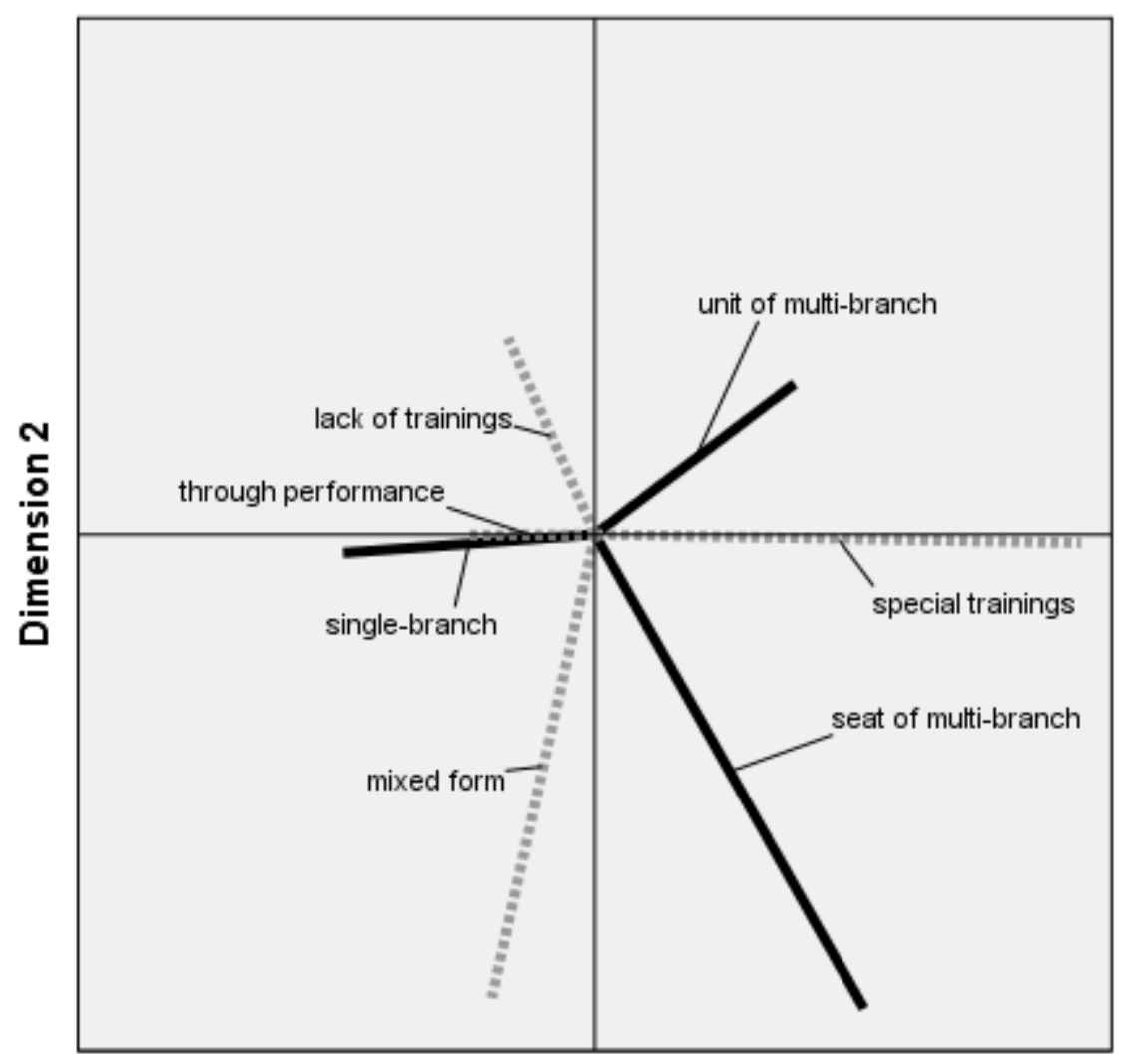

\section{Dimension 1}

Fig. 2. Results of the correspondence analysis for variables connected with trainings within the scope of databases and type of an enterprise (Source: author's compilation) 
The two dimensions again accounted for the whole inertia of the table. Dimension 1 accounts for $69.60 \%$ of inertia. The value of the chi-square test amounted to 12.803 , whereas the significance level reached $p=0.46$. It was not necessary to mark any of the categories as passive. Figure 2 presents the results of this analysis. It should be highlighted that the values of the category 'through performance of responsibilities' in particular dimensions are -0.252 and -0.001 , respectively.

Dimension 1 once again distinguished a single-branch enterprise from other types of enterprises. This time, however, the respondents representing the seats of multi-branch enterprises as well as their branches were more likely to point at 'special forms of trainings' (this concerns the structure of answers). However, a relatively large number of indications 'lack of trainings' was observed in case of units of multi-branch enterprises (dimension 2). Once again a single-branch enterprise had a significantly larger share in indications 'through performance of responsibilities' (approach of points). The variability of distribution was influenced by 'mixed form of trainings', 'special training' and 'seat of a multi-branch enterprise' (the longest vectors in particular groups of the category).

\section{Conclusions}

Literature analysis allowed visualising a broad description of the problems of employee trainings in the enterprise. However, if this topic is related to enterprise knowledge management, depending on the perspective of the analysis, it is possible to find atypical issues for well-known descriptions. In case of distinguishing a cold knowledge from the enterprise knowledge system, employee trainings appear to be a problem entangled in formal relationships in an enterprise and eventually between enterprises.

Grouping of respondents' indications concerning the forms of trainings applied in their enterprises within the scope of dissemination and preservation of formal rules of creating and applying internal documentation and databases revealed two things. First, trainings within the scope of databases were the main predictor that led to the distinction of groups. Second, the same form of training within the scope of internal documentation usually corresponded to a particular form of trainings within the scope of databases in case of three groups. The only exception was group 3 whose respondents stated that there are no trainings within the scope of databases within their enterprises. However, the main indications of this group concerning trainings within the scope of documentation were related to learning through performance of responsibilities. Therefore, it seems that this group was dominated by two forms of trainings of the lowest level of organisation.

The correspondence analysis made it possible to distinguish a single-branch enterprise from other forms of enterprises in case of both areas of trainings. Moreover, forms of trainings of a higher level of organisation had a relatively large share in the structure of respondents' indications in case of units of multi-branch enterprises as well as seats of such enterprises.

It should be made clear that in relations to a non-probabilistic sampling of respondents, the results of the conducted analysis may only be referred to the surveyed group of respondents. The method of selection of respondents and the structure of representation of types of enterprises derived from this fact influenced the answers obtained in the survey and are the main limitations of the research conducted.

However, it makes it possible to suppose that formal relationships within an enterprise, which may be a derivative of both organisational culture and organisational and legal subordination of a given entity, have a good influence on the selection of the form of training. As the results of the above study show, such a relationship between the formal rules of work within an enterprise and forms of trainings should be looked for, above all, within the scope of the so-called cold knowledge. Detailed recognition of these relationships as well as their potential confirmation on a representative group of respondents may constitute a subject of further studies.

\section{Acknowledgements}

The article presents the results of research tasks implemented within the framework of the project entitled 'The dynamics of strategic behaviours from the perspective of organisational learning' (stage 
I, 2016) financed by the funds for maintaining the scientific potential (supervisor Marcin Komańda, Ph.D.).

\section{References}

Aggestam, L. (2015). Learning organization or knowledge management-Which came first, the chicken or the egg?. Information Technology and Control, 35(3A), 295-302.

Albers, S., Wohlgezogen, F., \& Zajac, E. J. (2016). Strategic alliance structures: An organization design perspective. Journal of Management, 42(3), 582-614.

Andreeva, T., \& Kianto, A. (2012). Does knowledge management really matter? Linking knowledge management practices, competitiveness and economic performance. Journal of Knowledge Management, 16(4), 617-636.

Andreeva, T., \& Kianto, A. (2011). Knowledge processes, knowledge-intensity and innovation: a moderated mediation analysis. Journal of Knowledge Management, 15(6), 1016-1034.

Barrett, A., \& O'Connell, P. J. (2001). Does training generally work? The returns to in-company training. Industrial \& Labor Relations Review, 54(3), 647-662.

Billett, S. (2001). Learning in the workplace: Strategies for effective practice. St Leonards: Allen \& Unwin.

Dalkir, K., \& Liebowitz, J. (2011). Knowledge management in theory and practice. Massachusetts: MIT Press.

Driscoll, M. A. (2014). Growing a Learning Organization. In ACRL New England Chapter Annual Conference: We're All in This Together: Strengthening Librarians Through Professional Development, College of Holy Cross, Worcester, MA. Conference proceedings. [Accessed 21.05.2017]. Available from Internet: http://eprints.rclis.org/24624/

Donate, M. J., \& de Pablo, J. D. S. (2015). The role of knowledge-oriented leadership in knowledge management practices and innovation. Journal of Business Research, 68(2), 360-370.

Dziubińska, A. (2009). Konkurowanie w gospodarce opartej na wiedzy jako przestanka do modyfikacji modeli strategii korporacji międzynarodowych. In Wspótczesne $i$ perspektywiczne kierunki badań $w$ zarzadzaniu przedsiębiorstwami. J. Rokita, W. Czakon \& A. Samborski (Editors), Katowice: Akademia Ekonomiczna w Katowicach, 83-92.

Garvin, D. A. (2003). Learning in action: A guide to putting the learning organization to work. Boston: Harvard Business Review Press.

Geisler, E., \& Wickramasinghe, N. (2015). Principles of knowledge management: Theory, practice, and cases. New York: Routledge.

Ismail, M. (2005). Creative climate and learning organization factors: their contribution towards innovation. Leadership \& Organization Development Journal, 26(8), 639-654.

Jacobs, R. (2003). Structured on-the-job training: Unleashing employee expertise in the workplace. San Francisco: Berrett-Koehler Publishers, Inc.

Jaafar, M. N., Kassim, N. A., Ghazali, M. F. I. M., Idris, M. A., \& Khalib, M. L. H. (2014). Assessing Organizational Learning Culture, Leadership and Dialog in a Learning Organization. In Full Paper Proceeding ETAR-2014, Vol. 1. Conference proceedings, 1-13.

Jędralska, K., Komańda, M., \& Dziubińska, A. (2013). Kompetencje internacjonalizacyjne przedsiębiorstwa. Katowice: Uniwersytet Ekonomiczny w Katowicach.

Kim, D.H. (1998). The link between individual and organizational learning. In The Strategic Management of Intellectual Capital. D.A. Klein (Editor), Boston: Butterworth-Heinemann, 41-61.

Kisielinska, J. (2009). Bezwzorcowa klasyfikacja obiektów w ekonomice rolnictwa. Zeszyty Naukowe Szkoły Głównej Gospodarstwa Wiejskiego w Warszawie. Problemy Rolnictwa Światowego, 8, 104-115.

Komańda, M. (2016). Gorąca wiedza w przedsiębiorstwie. Organizacja i Zarzadzanie. Zeszyty Naukowe Politechniki Ślaskiej, 93, 197-206.

Komańda, M. (2017). Zimna wiedza w przedsiębiorstwie. Przeglad Organizacji, 1, 35-41.

Lendzion, J. P. (2015). Human resources management in the system of organizational knowledge management. 
Procedia Manufacturing, 3, 674-680.

Livitchi, O., Hacina, L., \& Baran, T. (2015). Professional training-effective element of management in achieving of the personnel policy. Economy Transdisciplinarity Cognition, 18(1), 156-162.

Martens, D.M. (2014), Research and Evaluation in Education and Psychology. Integrating Diversity with Quantitative, Qualitative and Mixed Methods. Los Angeles: Sage Publications, Inc.

Mathieu, J. E., \& Martineau, J. W. (1997). Individual and situational influences on training motivation. In Improving training effectiveness in work organizations. J.K. Ford (Editor), New York: Psychology Press, 193221.

Minbaeva, D. B. (2005). HRM practices and MNC knowledge transfer. Personnel Review, 34(1), $125-144$.

Minbaeva, D., Pedersen, T., Björkman, I., Fey, C. F., \& Park, H. J. (2003). MNC knowledge transfer, subsidiary absorptive capacity, and HRM. Journal of International Business Studies, 34(6), 586-599.

Ocieczek, W., Łakomy, K., \& Nowacki, K. (2016). The employee improvement process through training in light of the development of a work safety culture. Organizacja i Zarzadzanie, 4(36), 53-65.

Osterman, P. (1995). Skill, training, and work organization in American establishments. Industrial Relations: a Journal of Economy and Society, 34(2), 125-146.

Real, J. C., Roldán, J. L., \& Leal, A. (2014). From entrepreneurial orientation and learning orientation to business performance: analysing the mediating role of organizational learning and the moderating effects of organizational size. British Journal of Management, 25(2), 186-208.

Rezaei, M., Babadi, A. A. K., \& Mimaei, A. R. (2014). The Effect of Information Technology on the Quality of Employees' Trainings (Case Study: Employees of Iranian Bank Melli). International Science and Investigation Journal, 3(1), 1-9.

Rosenberg, M. J. (2001). E-learning: Strategies for delivering knowledge in the digital age (Vol. 3). New York: McGraw-Hill.

Rowley, J., \& Gibbs, P. (2008). From learning organization to practically wise organization. The Learning Organization, 15(5), 356-372.

Rószkiewicz M., Perek-Białas. J., Węziak-Białowolska D., \& Zięba-Pietrzak A. (2013). Projektowanie badań społeczno-ekonomicznych. Rekomendacje i praktyka badawcza. Warszawa: Wydawnictwo Naukowe PWN.

Ruggles, R. (2009). Knowledge management tools. Boston: Routledge.

Senge, P. M., Kleiner, A., Roberts, C., Ross, R., Roth, G., \& Smith, B. (1999). The dance of change: The challenges to sustaining momentum in a learning organization. New York: Doubleday/Currency Book.

Senge, P. M. (1997). The fifth discipline. Measuring Business Excellence, 1(3), 46-51.

Sergeev, A., \& Babkin, E. (2015). Towards Competence-Based Enterprise Restructuring Using Ontologies. Advances in Enterprise Engineering, IX, 34-46.

Sun, P. Y., \& Anderson, M. H. (2010). An examination of the relationship between absorptive capacity and organizational learning, and a proposed integration. International Journal of Management Reviews, 12(2), 130150.

Sztangret, I., Bilińska-Reformat, K. (2014). Knowledge management model in B2B relations - holistic approach on the example of IT products and trade sector. In the Trade Perspectives 2014. People, technology, knowledge. Conference proceedings, 34-54.

Vatansever, Ç., \& Karamaraş, S. (2017). Power of person-job fit: emotional labour for salespeople and its relation to job satisfaction. International Journal of Work Organisation and Emotion, 8(1), 1-23. 